\title{
The Role of Long Noncoding RNAs in Diabetic Alzheimer's Disease
}

\author{
Young-Kook Kim ${ }^{1}$ (D) and Juhyun Song ${ }^{2, *}$ \\ 1 Department of Biochemistry, Chonnam National University Medical School, Hwasun 58128, \\ Jeollanam-do, Korea; ykk@chonnam.ac.kr \\ 2 Department of Anatomy, Chonnam National University Medical School, Hwasun 58128, \\ Jeollanam-do, Korea \\ * Correspondence: juhyunsong@chonnam.ac.kr; Tel.: +82-061-379-2706
}

Received: 24 October 2018; Accepted: 19 November 2018; Published: 21 November 2018

check for updates

\begin{abstract}
Long noncoding RNAs (lncRNAs) are involved in diverse physiological and pathological processes by modulating gene expression. They have been found to be dysregulated in the brain and cerebrospinal fluid of patients with neurodegenerative diseases, and are considered promising therapeutic targets for treatment. Among the various neurodegenerative diseases, diabetic Alzheimer's disease (AD) has been recently emerging as an important issue due to several unexpected reports suggesting that metabolic issues in the brain, such as insulin resistance and glucose dysregulation, could be important risk factors for $\mathrm{AD}$. To facilitate understanding of the role of lncRNAs in this field, here we review recent studies on lncRNAs in AD and diabetes, and summarize them with different categories associated with the pathogenesis of the diseases including neurogenesis, synaptic dysfunction, amyloid beta accumulation, neuroinflammation, insulin resistance, and glucose dysregulation. It is essential to understand the role of lncRNAs in the pathogenesis of diabetic AD from various perspectives for therapeutic utilization of lncRNAs in the near future.
\end{abstract}

Keywords: LncRNAs; long noncoding RNAs; diabetic Alzheimer's disease; synaptic dysfunction; inflammation; insulin resistance

\section{Introduction}

Long noncoding RNAs (lncRNAs) are a class of noncoding RNAs [1] that regulate diverse physiological processes by controlling gene expression [2]. The sequences of most lncRNAs are longer than 200 nucleotides (nt) and do not have protein coding potential. They have been reported to be involved in various diseases, including cancer and cardiovascular and neurodegenerative diseases [3-6]. Among these, the roles of various lncRNAs have been recently reported in Alzheimer's disease (AD) [7-10]. Considering the diverse roles and mechanism of action of lncRNAs, their utilization for the treatment of $\mathrm{AD}$ may be an appropriate approach for achieving high therapeutic effectiveness.

Diabetic AD is a newly emerging concept in the field of neurodegenerative diseases [11]. Risk factors for type 2 diabetes mellitus (T2DM), including impaired glucose homeostasis and insulin resistance, are believed to contribute to the onset and progression of AD [12-14]. With increasing age, metabolic failures trigger hyperglycemia and insulin resistance, leading to T2DM, and subsequently increase the risk of diabetic AD [15-17]. As previously mentioned, lncRNAs are broadly involved in AD pathogenesis through diverse mechanisms. Presently, the manipulation of diabetic AD-related lncRNAs in the brains of patients with $\mathrm{AD}$ is considered a novel therapeutic approach. Here, we broadly review the roles of 1 ncRNAs in diabetes and $A D$, and suggest the therapeutic feasibility of IncRNAs against diabetic AD pathogenesis. 


\section{Diabetic Alzheimer's Disease}

The characteristic features of AD are memory dysfunction and cognitive decline, which are triggered by neurodegeneration resulting from amyloid beta $(\mathrm{A} \beta)$ accumulation and tau protein hyperphosphorylation in the brain [18]. Also, decades of research demonstrated that mutations in APP and the two presenilin genes (PS1 and PS2) can trigger the development of AD though misprocessing of APP [19-21]. Several studies have shown that diabetes could increase the risk of AD by influencing cognitive defects and insulin resistance in the brain $[13,14]$. One study revealed that T2DM enhances $A \beta$ aggregation, which leads to severe $A \beta$ pathology [22]. Another study reported that diabetes worsened amyloid plaque and neurofibrillary tangle formation in the brain of a triple transgenic $\mathrm{AD}$ mouse model [12].

Hyperglycemia is known to trigger neuronal death by boosting the production of advanced glycation products and by promoting glucose shunting [23]. Additionally, it was reported that T2DM caused by a high-fat diet is an important risk factor for cognitive dysfunction [24,25]. A study using insulin-resistant mice revealed memory deficits and impaired hippocampal insulin signaling in this animal model [26]. Further, AD transgenic mice fed a high-fat diet showed higher accumulation of higher accumulation of $A \beta$ and tau protein in the cerebral cortex [27]. In a clinical study, patients with T2DM showed reduced hippocampal volume and impaired cognitive function compared to healthy subjects [28]. Previous studies suggested that diabetes is a strong risk factor for AD [11] and diabetes-induced $\mathrm{AD}$ has been emerging as a major pathogenic mechanism of $\mathrm{AD}[29,30]$. Several studies demonstrated that hyperinsulinemia and insulin resistance triggers cognitive impairment and $\mathrm{A} \beta$ and amyloid precursor protein (APP) deposition [31-34]. Additionally, AD can be influenced by impaired insulin signaling [35], suggesting that tau hyperphosphorylation is regulated through insulin and the insulin-like growth factor signaling pathway [36]. The potential influence of diabetes on the onset and development of AD should be highlighted to prevent the global increase of AD. Further, considering previous broad findings, diabetic AD should be investigated in greater detail to find methods to attenuate the risk of $\mathrm{AD}$ onset and to understand the detailed mechanism of AD pathogenesis.

\section{What is LncRNAs?}

Noncoding RNAs (ncRNAs) are generally divided into two groups based on their sizes: small $(<200 \mathrm{nt}$ ) and long (> $200 \mathrm{nt}$ ) (Figure 1A). The small ncRNAs include transfer RNAs, small nucleolar RNAs, small nuclear RNAs, and microRNAs (miRNAs), whereas lncRNAs include heterogeneous classes of regulatory RNAs, such as antisense RNAs, enhancer RNAs, and long intergenic noncoding RNAs (lincRNAs) [37-39]. As regulatory ncRNAs, more lncRNAs exist in the human genome than miRNAs, but the function of lncRNAs is understood less well (Figure 1). Various loci in the genome encode lncRNAs: enhancers, promoters, introns of protein-coding genes, and intergenic regions [40]. Most lncRNAs are transcribed by RNA polymerase II and are $5^{\prime}$-capped but only a subset of lncRNAs are polyadenylated. They are spliced using the consensus splicing signals that are used for mRNAs $[39,41]$. The sequences of lncRNAs are characterized by their attenuated conservation across species, and fewer exons are observed than protein-coding transcripts [42,43]. Numerous studies have found that lncRNAs influence physiological processes by controlling gene expression at the transcriptional and posttranscriptional levels [44,45]. In cells, lncRNAs are localized in both the nucleus and cytoplasm [46], and they function through distinct mechanisms depending on their cellular localization [47]. In the nucleus, IncRNAs act as transcriptional activators or inhibitors in cis (to control neighboring genes on the same chromosome) or in trans (to control genes at distant regions of the same chromosome or on other chromosomes). These nuclear lncRNAs exert their functions via various mechanisms, including recruitment of chromatin modification complexes into essential genomic loci to influence DNA methylation $[46,48]$, and act as transcriptional coactivators $[47,49,50]$. In contrast, lncRNAs in the cytoplasm mostly act as molecular decoys for proteins or miRNAs. In addition to their roles as transcriptional or post-transcriptional regulators, some lncRNAs have functions that 
are entirely independent of gene regulation, such as chromosome segregation, DNA damage repair, and genome stability [51,52].

LncRNAs have been implicated as modulators of various cellular mechanisms including regulation of RNA stability, cell cycle, and chromatin structure [53-55]. Dysregulation of lncRNAs has been implicated in the pathogenesis of many diseases, such as cancer [56,57] and cardiovascular diseases [58,59]. Moreover, recent studies have reported the importance of lncRNAs in the pathogenesis of diabetes, obesity, and neuronal diseases [60-63] (Table 1). Some lncRNAs, including myocardial infarction associated transcript (MIAT), metastasis-associated lung adenocarcinoma transcript 1 (MALAT1), and nuclear enriched abundant transcript 1 (NEAT1), influence neurodegenerative diseases [60] such as Huntington's disease [61,62] and AD [64,65]. Importantly, MALAT1 was shown to be involved in the regulation of synaptic density, hepatic steatosis, and insulin resistance $[66,67]$. Another IncRNA H19 promotes neuroinflammation, and is also involved in insulin signaling and glucose uptake $[68,69]$. Thus, these lncRNAs are good candidate links between diabetes and AD that can be explored in future studies. Although there are considerably more lncRNAs than miRNAs in cells, fewer studies have been conducted on the functions of lncRNAs than on the functions of miRNAs, highlighting the importance of future studies on IncRNAs (Figure 1). In this review, we tried to identify important lncRNAs in the diabetic AD brain and the role of these lncRNAs focused on neurogenesis, neuroinflammation, synaptic dysfunction, $A \beta$ accumulation, insulin resistance, and glucose homeostasis.

Table 1. List of lncRNAs related to neurogenesis and synaptic function, $\mathrm{A} \beta$ accumulation, immune response, insulin signaling and glucose homeostasis. Only those with known mechanisms were selected. The genomic loci of lncRNAs are shown based on the genomic coordinates at hig genome assembly for humans or at mm10 assembly for mice, respectively.

\begin{tabular}{|c|c|c|c|c|}
\hline LncRNA & $\begin{array}{l}\text { Genomic Locus } \\
\text { (hg19 or mm10) }\end{array}$ & Function & Mechanism & Reference \\
\hline \multicolumn{5}{|c|}{ Neurogenesis and synaptic function } \\
\hline Evf2 & $\begin{array}{c}\text { chr6:6820543-6871592 } \\
\text { (mouse) }\end{array}$ & $\begin{array}{l}\text { Evf2 mouse mutants had fewer } \\
\text { GABAergic interneurons in the } \\
\text { early postnatal hippocampus } \\
\text { and dentate gyrus }\end{array}$ & $\begin{array}{l}\text { Recruited DLX and MECP2 transcription } \\
\text { factors to important DNA regulatory } \\
\text { elements in the Dlx5/6 intergenic region and } \\
\text { controlled Dlx5, Dlx6 and Gad1 expression }\end{array}$ & [72] \\
\hline Miat & $\begin{array}{c}\text { chr5:112213228-112228948 } \\
\text { (mouse) }\end{array}$ & $\begin{array}{l}\text { Involved in neurogenic } \\
\text { commitment }\end{array}$ & $\begin{array}{l}\text { Manipulation of Miat triggers pleiotropic } \\
\text { effects on brain development and aberrant } \\
\text { splicing of Wnt7b }\end{array}$ & [60] \\
\hline Pnky & $\begin{array}{c}\text { chr4:22490548-22493126 } \\
\text { (mouse) }\end{array}$ & $\begin{array}{l}\text { Regulates neurogenesis from } \\
\text { embryonic and postnatal neural } \\
\text { stem cell populations }\end{array}$ & $\begin{array}{l}\text { Pnky interacts with the splicing } \\
\text { regulator PTBP1 }\end{array}$ & [73] \\
\hline PVT1 & $\begin{array}{c}\text { chr15:62037986-62250976 } \\
\text { (mouse) }\end{array}$ & $\begin{array}{l}\text { Decreased by autophagic } \\
\text { inhibition in diabetes }\end{array}$ & $\begin{array}{l}\text { PVT1-mediated autophagy may protect } \\
\text { hippocampal neurons from impairment of } \\
\text { synaptic plasticity and apoptosis, and } \\
\text { ameliorate cognitive impairment in diabetes }\end{array}$ & [74] \\
\hline RMST & $\begin{array}{c}\text { chr12:97858799-97927544 } \\
\text { (human) }\end{array}$ & $\begin{array}{l}\text { Regulation of neural stem cell } \\
\text { fate }\end{array}$ & $\begin{array}{l}\text { RMST is required for the binding of SOX } 2 \text { to } \\
\text { promoter regions of neurogenic transcription } \\
\text { factors }\end{array}$ & [75] \\
\hline
\end{tabular}


Table 1. Cont.

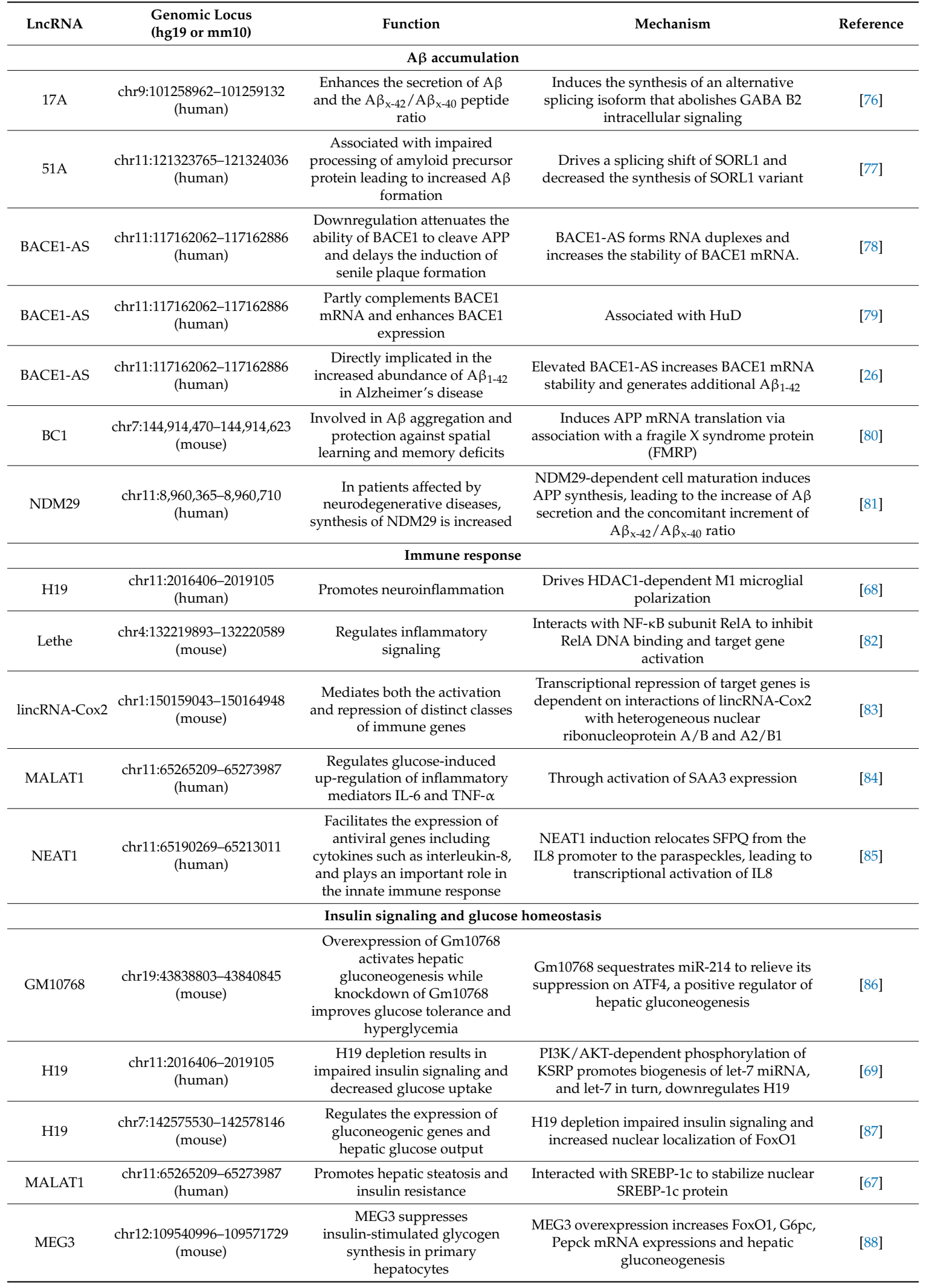


Table 1. Cont.

\begin{tabular}{|c|c|c|c|c|}
\hline LncRNA & $\begin{array}{l}\text { Genomic Locus } \\
\text { (hg19 or mm10) }\end{array}$ & Function & Mechanism & Reference \\
\hline PCGEM1 & $\begin{array}{c}\text { chr2:193614571-193641625 } \\
\text { (human) }\end{array}$ & $\begin{array}{l}\text { Promotes glucose uptake for } \\
\text { aerobic glycolysis, coupling } \\
\text { with the pentose phosphate } \\
\text { shunt to facilitate biosynthesis } \\
\text { of nucleotide and lipid, and } \\
\text { generates nicotinamide adenine } \\
\text { dinucleotide phosphate } \\
\text { (NADPH) for redox homeostasis }\end{array}$ & $\begin{array}{l}\text { Binds directly to target promoters, physically } \\
\text { interacts with c-Myc, promotes chromatin } \\
\text { recruitment of c-Myc, and enhances its } \\
\text { transactivation activity }\end{array}$ & [89] \\
\hline Risa & $\begin{array}{c}\text { chr10:63339203-63340913 } \\
\text { (mouse) }\end{array}$ & Regulates insulin sensitivity & $\begin{array}{c}\text { Overexpression of Risa decreases autophagy } \\
\text { while knockdown of Risa up-regulates } \\
\text { autophagy }\end{array}$ & [90] \\
\hline SRA & $\begin{array}{c}\text { chr18:36667187-36670311 } \\
\text { (mouse) }\end{array}$ & $\begin{array}{l}\text { SRA KO mice are resistant to } \\
\text { high fat diet-induced obesity, } \\
\text { with decreased fat mass and } \\
\text { increased lean content, and } \\
\text { more insulin sensitivity }\end{array}$ & $\begin{array}{c}\text { Functions as a transcriptional coactivator of } \\
\text { PPAR } \gamma \text { and promotes adipocyte } \\
\text { differentiation in vitro }\end{array}$ & [8] \\
\hline
\end{tabular}

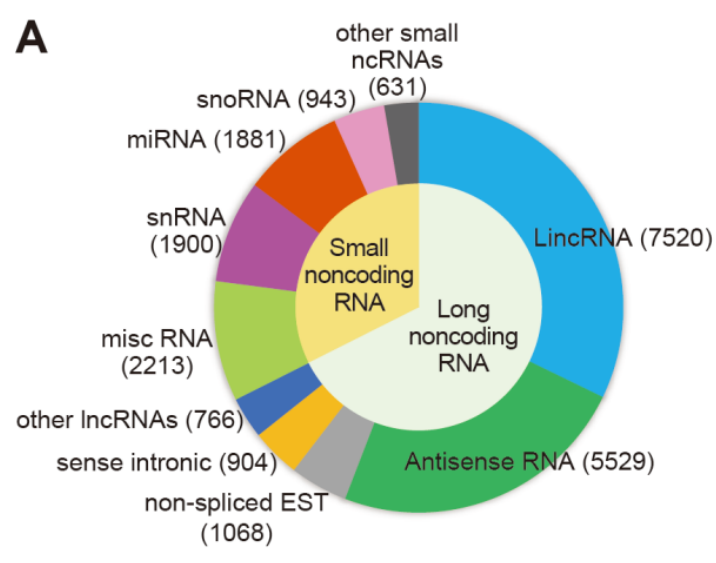

\section{B}

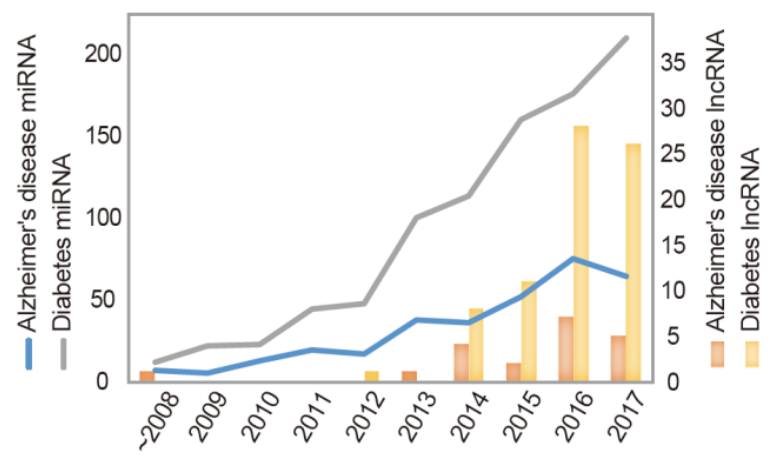

Figure 1. The classification of noncoding RNAs (ncRNAs) and the number of papers published on the study of ncRNAs in Alzheimer's disease (AD) and diabetes. (A) The number of ncRNAs identified in humans. The classification of ncRNAs is based on GENCODE (Version 26, October 2016) [92]. The number of ncRNAs in each group is indicated in parentheses. (B) The number of research papers on long ncRNAs (lncRNAs) and microRNAs (miRNAs) in AD and diabetes published in the past 10 years is shown. The papers were located in PubMed and review papers were excluded. Note that although the number of lncRNAs, including long intergenic ncRNAs (lincRNAs), antisense RNAs, and sense intronic RNAs, is larger than that of regulatory small RNAs, only a few papers have been published on lncRNAs in AD and diabetes compared to those published on miRNAs. EST: expressed sequence tag, snRNA: small nuclear RNA, snoRNA: small nucleolar RNA. 


\section{LncRNAs in AD}

Current studies have reported that the expression patterns of lncRNAs appear disrupted in the brain, blood, and cerebrospinal fluid (CSF) of patients with AD compared to those in normal subjects. There have been reports of lncRNAs that are dysregulated in the brains of patients with AD [40]. Moreover, lncRNAs, including RP11-462G22.1 and PCA3, were upregulated in exosomes derived from the CSF of patients with AD compared to normal subjects [93]. For example, in an in vitro AD model, the expression of antisense ubiquitin carboxyl-terminal hydrolase L1 (antisense Uchl1) increased, and this in turn led to an increase in the synthesis of the UCHL1 protein, a deubiquitinating enzyme involved in AD pathogenesis, at the posttranscriptional level [70]. Although several studies have reported the relationship between the altered expression of lncRNAs and AD progression, more efforts are necessary to understand the regulatory mechanisms of specific lncRNAs in the brain, blood, and CSF of patients with AD. Moreover, the study of lncRNAs involved in the link between the onset of $\mathrm{AD}$ and $\mathrm{T} 2 \mathrm{DM}$ and involving $\mathrm{A} \beta$ accumulation or neuroinflammation is required to elucidate the related mechanisms and to find the solution to inhibit these pathogeneses. Hence, we summarize the known lncRNAs involved in these processes below.

\section{LncRNAs Control Neurogenesis}

The regulation of neurogenesis is an important issue for $\mathrm{AD}$ as impaired neurogenesis leads to cognitive impairments through neuronal loss and synaptic dysfunction [94,95]. Neural stem cells (NSCs), which have the ability of self-renewal, ultimately differentiate into neurons or neuroglia depending on the action of numerous trophic factors $[96,97]$. Neurogenesis occurs mainly in the anterior part of the subventricular zone and in the subgranular zone of the hippocampus $[96,98]$. In the brain, hippocampal neurogenesis has a critical role in memory function and is influenced by growth factors including brain-derived neurotrophic factor, insulin growth factor-1, and vascular endothelial growth factor [99]. Several lncRNAs play roles in the glial and neuronal differentiation of NSCs $[100,101]$. One study listed the IncRNAs that are associated with neuronal differentiation [60], and others have identified several lncRNAs involved in the regulation of neural lineage specification and neuron-glia fate switching [102-104]. Further, several lncRNAs are involved in hippocampal neuronal maturation and oligodendrocyte differentiation and maturation by modulating the epigenetic status of protein-coding genes [41,103]. Additionally, two lncRNAs, NEAT1 and MALAT1, can upregulate neurogenesis by controlling neurite outgrowth and neuronal fate $[102,104,105]$. Neurite outgrowth is an essential process of neuronal differentiation and also plays an important role in neuronal regeneration and injury response [106]. It is a biological mechanism involving complicated regulation of gene expression and signal transduction [106]. Moreover, it was reported that lncRNAs, including RMST, are involved in neuronal differentiation [75]; RMST could increase neuronal differentiation by physically interacting with SOX2 (a transcription factor known to regulate neural fate) and by binding to promoter regions of genes encoding neurogenic transcription factors. Considering this evidence for the role of lncRNAs in neural differentiation and maturation and glial differentiation, further studies on lncRNAs are required to investigate the regulation of neurogenesis in diabetic $\mathrm{AD}$, given that diabetes leads to impaired neurogenesis and aggravates the progression of AD [107]. The modulation of neurogenesis-associated lncRNAs in diabetic AD may be an important key to improve neurogenesis and ultimately to inhibit memory dysfunction.

\section{LncRNAs Regulate Synaptic Dysfunction in AD}

Synaptic dysfunction is a critical issue in the pathogenesis of $\mathrm{AD}$ since it drives cognitive decline $[108,109]$. Synaptic dysfunction occurs in various cortical circuits of the brain, from the entorhinal cortex to the hippocampus [110,111]. Impaired synaptic plasticity results in a decreased number of synapses between neurons, and neuronal loss, which leads to cognitive dysfunction in AD [112]. Previous studies have shown that the lncRNA $B C 1 / B C 200$ influences synaptic 
plasticity $[113,114]$. It was reported that the expression of $B C 200$ was lower in the brains of patients with AD than that in the brains of normal subjects, and that structural disturbance in the BC200 RNA resulted in the inhibition of dendritic delivery [65]. Inadequate translational modulation was observed in $B c 1$ knockout mice, and this triggered neuronal hyper-excitability and the blockade of extracellular signal-regulated kinase-mitogen-activated protein kinase kinase signaling [115]. Another study found that $B C 1$ RNA could contribute to the regulation of striatal $\gamma$-aminobutyric acid (GABA) synapses through dopamine receptor D2 in AD [116]. Furthermore, the lncRNA Gomafu is expressed throughout the brain [117], and its dysregulation leads to synapse dysfunction by triggering aberrant splicing of ERRB4 [118]. Thus, several lncRNAs could regulate synaptic plasticity in AD, suggesting that it would be plausible to reverse impaired synaptic plasticity by modulating these lncRNAs. Given that the improvement of impaired synaptic plasticity could resolve memory dysfunction in diabetic AD, the identification of lncRNAs related to synaptic plasticity is essential to find a therapeutic solution.

\section{LncRNAs Modulate A $\beta$ Accumulation in AD}

APP is cleaved by the $\beta$-site amyloid precursor protein cleaving enzyme 1 (BACE1 or $\beta$-secretase 1 ) and $\gamma$-secretase, leading to the production of $A \beta$ peptides [119]. Abnormal $A \beta$ clearance and increase in BACE1 activity promoted $A \beta$ accumulation and aggravated AD progression [119]. Several lncRNAs were shown to regulate the expression of APP and BACE1 in the brains of patients with $\operatorname{AD}[77,120]$. For example, neuronal sortilin-related receptor gene (SORL1) is known to influence the cleavage of APP and lead to the inhibition of A $\beta$ formation in the brains of patients with AD [120]. The lncRNA 51A, mapped at an antisense orientation to intron 1 of SORL1 [121], was overexpressed in the brain of patients with $\mathrm{AD}$ and was found to enhance $\mathrm{A} \beta$ formation [77]. The increase in 51A expression markedly decreased SORL1 levels, possibly by controlling the splicing pattern of the SORL1 transcript [77]. In the brains of patients with AD, the mRNA levels of BACE1, which contributes to the development of $\mathrm{AD}$, are reduced in the cortex, dorsal hippocampus, and ventral hippocampus, but not in the cerebellum [26,122]. Loss of BACE1 triggers behavioral deficits, such as memory loss [123] and loss of synaptic plasticity [124]. The levels of the lncRNA BACE1-AS, which is transcribed in an antisense orientation to $B A C E 1$, is considerably increased in $\mathrm{AD}$, and its overexpression could elevate $A \beta_{1-42}$ levels [7,125]. Further, BACE1-AS could regulate the mRNA levels of BACE1, which increases $A \beta$ production [26]. Moreover, this lncRNA binds to $\mathrm{HuD}$, an RNA-binding protein associated with learning and memory function, and influences APP cleavage [79]. In the neuroblastoma cell line SH-SY5Y, an in vitro model of AD, the lncRNAs $17 A$ and neuroblastoma differentiation marker 29 (NDM29) were significantly upregulated; this in turn promoted the accumulation of $A \beta[76,81]$. An RNA polymerase III-transcribed ncRNA regulated by an extragenic type-3 promoter [126], NDM29, is also involved in the synthesis of APP, leading to increased A $\beta$ secretion $[127,128]$. Other studies have also shown that NDM29 contributes to $A \beta$ formation by regulating its cleavage $[129,130]$. This evidence indicates that lncRNAs contribute to the accumulation of $A \beta$ through diverse mechanisms and ultimately affect the pathogenesis of AD. It is necessary to elucidate the mechanisms between candidate lncRNAs and $A \beta$ accumulation to attenuate $A \beta$ accumulation in the brain which may lead to a therapeutic approach against AD.

\section{LncRNAs Contribute to the Regulation of Neuroinflammation in AD}

Inflammatory signaling is an important factor for brain homeostasis, repair, and neuroprotection [105]. In $\mathrm{AD}$, the inflammatory response is a key hallmark because it aggravates the pathogenesis of $\mathrm{AD}$ [131]. The accumulation of $\mathrm{A} \beta$ leads to excessive oxidative stress and triggers severe neuroinflammation [128,132]. Several studies have reported that lncRNAs influence immune responses [133,134]. Interestingly, many genes encoding immune-related lncRNAs including IL1ß-RBT46 [135], LincR-Ccr2-5' AS [136], and lnc-IL7R [137], are located close to immune-responsible protein coding gene clusters, suggesting that these lncRNAs and proteins are under a common signaling pathway. It was demonstrated that the lncRNA LincRNA-Cox2 activates 
immune genes in macrophages and mediates the activation of NF- $\mathrm{KB}$ [83]. This lncRNA works by binding with the RNA-binding proteins HNRNPA/B and HNRNPA2/B1 and by enhancing the expression of interleukin (IL)-6 through toll-like receptors. Further, defects in the lncRNA Lethe trigger the upregulation of NFKBIA and NFKB2, and lead to the blockage of NF- $\mathrm{KB}$ activation [82]. Additionally, lncRNA H19 promotes neuroinflammation by regulating M1 microglial polarization through histone deacetylases [68]. In the neuroinflammatory response, NEAT1, the lncRNA known to regulate the formation of the nuclear paraspeckle body, also stimulated the expression of IL-8, which is associated with cognitive dysfunction $[85,138,139]$. Moreover, NDM29 was shown to be involved in the proinflammatory response in patients with $A D$ [81]. Furthermore, $17 A$ decreased the transcription of the GABA B2 receptor, which remarkably impaired the GABAB signaling pathway and enhanced neuroinflammation in AD brains [76]. As mentioned above, neuroinflammation is an important cause in neuronal damage [140-142] and simultaneously, the identification and modulation of neuroinflammation-related lncRNAs may be a good approach to treat neuropathies caused by diabetes-induced AD.

\section{LncRNAs Control Insulin Resistance and Glucose Homeostasis}

Insulin resistance is characterized by impaired insulin action in maintaining glucose homeostasis [143]. Given that insulin resistance in the brain is a crucial risk factor for AD and aggravates the pathogenesis of $\mathrm{AD}[144,145]$, further studies on the relationship between AD and insulin resistance in the brain are warranted to investigate possible therapeutic approaches against AD. Since glucose dysregulation in the brain is expected to be one of the causes of AD [146], it is interesting that several studies have revealed the regulation of glucose homeostasis by lncRNAs $[147,148]$. Further, numerous other studies have found that lncRNAs play crucial roles in the progression of T2DM through processes including insulin resistance and impaired glucose homeostasis [149-151]. One study reported that interference of the lncRNA maternally expressed gene 3 (Meg3) reduced the levels of triglycerides and attenuated impaired glucose tolerance in a high-fat diet fed obesity mouse model [88]. Additionally, $\mathrm{Meg} 3$ was shown to promote insulin resistance in a mouse model of type 1 diabetes mellitus (T1DM) and T2DM [152]. Knockdown of Meg3 reduced insulin synthesis and its inactivation decreased the synthesis and secretion of insulin, leading to glucose tolerance. Furthermore, a study of patients with diabetes revealed an association between a SNP (rs941576), located on an intron of MEG3, with T1DM [153]. In addition, H19 lncRNA, which was decreased in human diabetic subjects and insulin resistant mice, could regulate glucose homeostasis by acting as a molecular sponge for let-7 miRNAs [89]. Plasmacytoma variant translocation 1 (PVT1), a lncRNA stimulated by glucose, was shown to be associated with T1DM and T2DM [147]. Further, the expression of MIAT was upregulated in the vascular endothelial cells of diabetic rats, as well as those of patients with diabetes, under high-glucose conditions [154]. Another study reported that the lncRNA steroid receptor RNA activator $(S R A)$ was shown to exist in a ribonucleoprotein complex bound with the trithorax group or polycomb repressive complex 2 and modulate gene expression [155]; SRA could increase the expression of the insulin receptor and enhance insulin signaling by blocking the phosphorylation of c-Jun, N-terminal kinase, and p38 mitogen-activated protein kinase [8]. The mature adipocytes of $S R A$ knockout mice exhibited decreased insulin sensitivity resulting from reduced phosphorylation of insulin receptor substrate- 1 and decreased glucose levels in the brains of high-fat diet fed mice [8]. Furthermore, it was shown that MALAT1 expression was increased in the liver of obese mice and promoted hepatic insulin resistance by activating the stability nuclear sterol regulatory element binding transcription factor 1c (SREBP-1C) [67]. This lncRNA was also implicated in its association with the pathogenesis of diabetes-related microvascular diseases [156], and its knockdown suppressed the viability of endothelial cells [157] and inhibited the expression of inflammatory marker genes [84]. Interestingly, in addition to its roles in insulin resistance, the function and working mechanism of MALAT1 were also studied in neuronal process as described above $[66,105]$, implying that this lncRNA might be an example of lncRNA linking both processes. Thus, an important study in the future will 
be the identification of the role of MALAT1 in diabetic AD patients or related experimental models. Since insulin resistance and impaired glucose homeostasis in the brain lead to aggravation of AD progression [158], the lncRNAs associated with these processes merit further investigation to identify therapeutic approaches against AD.

\section{Conclusions}

As the research field of lncRNAs continues to expand worldwide, the knowledge of how lncRNAs act at a cellular level in diabetic AD is also gradually increasing. In this review, we summarized the relationship between lncRNAs and diabetic AD pathogenesis based on recent evidence. Several IncRNAs were associated with diverse processes in the brain underlying the pathogenesis of diabetic $\mathrm{AD}$, including impaired neurogenesis, synaptic dysfunction, $\mathrm{A} \beta$ accumulation, neuroinflammation, insulin resistance, and impaired glucose homeostasis. To our knowledge, most lncRNAs related to diabetic AD have been discussed in this review, but investigation of lncRNAs on diabetic AD is still in the early stage. We highlight that lncRNAs are desirable candidates for future studies on diabetic AD biomarkers and the information about lncRNAs in this review may help suggest potential diabetic AD treatments. The comprehensive understanding of lncRNA in AD and diabetes may help us attenuate AD pathology. As more discoveries on the changes in lncRNA expression associated with diabetic AD will be made, we can utilize those lncRNAs as the biomarkers for the disease status of diabetic AD. Furthermore, the modulation of lncRNA expression using genome engineering technologies will enable us to apply clinically relevant lncRNAs into the therapy of diabetic AD. Hence, we suggest that further studies regarding the roles of IncRNAs in diabetic AD are essential to identify advanced therapeutic approaches against the disease.

Author Contributions: Y.-K.K. performed the analysis in the figure. Y.-K.K. and J.S. wrote the manuscript.

Funding: This study was supported by the Basic Science Research Program through the National Research Foundation of Korea (NRF), funded by a grant from 2016R1D1A1B03930394 (Juhyun Song) and NRF-2018R1A2B6001104 (Young-Kook Kim).

Conflicts of Interest: The authors have no conflicts of interest to declare.

\section{Abbreviation Lists}

Amyloid beta $\quad \mathrm{A} \beta$

Amyloid beta precursor protein APP

Alzheimer's disease AD

Long noncoding RNAs lncRNAs

Noncoding RNAs ncRNAs

Type 2 diabetes mellitus T2DM

\section{References}

1. Knauss, J.L.; Sun, T. Regulatory mechanisms of long noncoding RNAs in vertebrate central nervous system development and function. Neuroscience 2013, 235, 200-214. [CrossRef] [PubMed]

2. Melissari, M.T.; Grote, P. Roles for long non-coding RNAs in physiology and disease. Pflug. Arch. Eur. J. Physiol. 2016, 468, 945-958. [CrossRef] [PubMed]

3. Kraus, T.F.; Greiner, A.; Guibourt, V.; Lisec, K.; Kretzschmar, H.A. Identification of Stably Expressed lncRNAs as Valid Endogenous Controls for Profiling of Human Glioma. J. Cancer 2015, 6, 111-119. [CrossRef] [PubMed]

4. Khorkova, O.; Hsiao, J.; Wahlestedt, C. Basic biology and therapeutic implications of lncRNA. Adv. Drug Deliv. Rev. 2015, 87, 15-24. [CrossRef] [PubMed]

5. Riva, P.; Ratti, A.; Venturin, M. The Long Non-Coding RNAs in Neurodegenerative Diseases: Novel Mechanisms of Pathogenesis. Curr. Alzheimer Res. 2016, 13, 1219-1231. [CrossRef] [PubMed]

6. Zhang, X.Q.; Wang, Z.L.; Poon, M.W.; Yang, J.H. Spatial-temporal transcriptional dynamics of long non-coding RNAs in human brain. Hum. Mol. Genet. 2017, 26, 3202-3211. [CrossRef] [PubMed] 
7. Modarresi, F.; Faghihi, M.A.; Patel, N.S.; Sahagan, B.G.; Wahlestedt, C.; Lopez-Toledano, M.A. Knockdown of BACE1-AS Nonprotein-Coding Transcript Modulates Beta-Amyloid-Related Hippocampal Neurogenesis. Int. J. Alzheimer's Dis. 2011, 2011, 929042. [CrossRef] [PubMed]

8. Liu, S.; Sheng, L.; Miao, H.; Saunders, T.L.; MacDougald, O.A.; Koenig, R.J.; Xu, B. SRA gene knockout protects against diet-induced obesity and improves glucose tolerance. J. Biol. Chem. 2014, 289, 13000-13009. [CrossRef] [PubMed]

9. Lee, D.Y.; Moon, J.; Lee, S.T.; Jung, K.H.; Park, D.K.; Yoo, J.S.; Sunwoo, J.S.; Byun, J.I.; Shin, J.W.; Jeon, D.; et al. Distinct Expression of Long Non-Coding RNAs in an Alzheimer's Disease Model. J. Alzheimer's Dis. 2015, 45, 837-849. [CrossRef] [PubMed]

10. Luo, Q.; Chen, Y. Long noncoding RNAs and Alzheimer's disease. Clin. Interv. Aging 2016, 11, 867-872. [CrossRef] [PubMed]

11. De la Monte, S.M.; Wands, J.R. Alzheimer's disease is type 3 diabetes-evidence reviewed. J. Diabetes Sci. Technol. 2008, 2, 1101-1113. [CrossRef] [PubMed]

12. Hayashi-Park, E.; Ozment, B.N.; Griffith, C.M.; Zhang, H.; Patrylo, P.R.; Rose, G.M. Experimentally induced diabetes worsens neuropathology, but not learning and memory, in middle aged 3xTg mice. Behav. Brain Res. 2017, 322, 280-287. [CrossRef] [PubMed]

13. Ashby, E.L.; Miners, J.S.; Kehoe, P.G.; Love, S. Effects of Hypertension and Anti-Hypertensive Treatment on Amyloid-beta (Abeta) Plaque Load and Abeta-Synthesizing and Abeta-Degrading Enzymes in Frontal Cortex. J. Alzheimer's Dis. 2016, 50, 1191-1203. [CrossRef] [PubMed]

14. Bakris, G.L.; Fonseca, V.A.; Sharma, K.; Wright, E.M. Renal sodium-glucose transport: Role in diabetes mellitus and potential clinical implications. Kidney Int. 2009, 75, 1272-1277. [CrossRef] [PubMed]

15. Ford, E.S.; Giles, W.H.; Dietz, W.H. Prevalence of the metabolic syndrome among US adults: Findings from the third National Health and Nutrition Examination Survey. JAMA 2002, 287, 356-359. [CrossRef] [PubMed]

16. Morley, J.E. Diabetes and aging: Epidemiologic overview. Clin. Geriatr. Med. 2008, 24, 395-405. [CrossRef] [PubMed]

17. Janson, J.; Laedtke, T.; Parisi, J.E.; O’Brien, P.; Petersen, R.C.; Butler, P.C. Increased risk of type 2 diabetes in Alzheimer disease. Diabetes 2004, 53, 474-481. [CrossRef] [PubMed]

18. Kolarova, M.; Garcia-Sierra, F.; Bartos, A.; Ricny, J.; Ripova, D. Structure and pathology of tau protein in Alzheimer disease. Int. J. Alzheimer's Dis. 2012, 731526. [CrossRef] [PubMed]

19. Kametani, F.; Hasegawa, M. Reconsideration of Amyloid Hypothesis and Tau Hypothesis in Alzheimer's Disease. Front. Neurosci. 2018, 12, 25. [CrossRef] [PubMed]

20. Munter, L.M.; Botev, A.; Richter, L.; Hildebrand, P.W.; Althoff, V.; Weise, C.; Kaden, D.; Multhaup, G. Aberrant amyloid precursor protein (APP) processing in hereditary forms of Alzheimer disease caused by APP familial Alzheimer disease mutations can be rescued by mutations in the APP GxxxG motif. J. Biol. Chem. 2010, 285, 21636-21643. [CrossRef] [PubMed]

21. Xu, T.H.; Yan, Y.; Kang, Y.; Jiang, Y.; Melcher, K.; Xu, H.E. Alzheimer's disease-associated mutations increase amyloid precursor protein resistance to gamma-secretase cleavage and the Abeta42/Abeta40 ratio. Cell Dis. 2016, 2, 16026. [CrossRef] [PubMed]

22. Okabayashi, S.; Shimozawa, N.; Yasutomi, Y.; Yanagisawa, K.; Kimura, N. Diabetes mellitus accelerates Abeta pathology in brain accompanied by enhanced GAbeta generation in nonhuman primates. PLoS ONE 2015, 10, e0117362. [CrossRef] [PubMed]

23. Giacco, F.; Brownlee, M. Oxidative stress and diabetic complications. Circ. Res. 2010, 107, 1058-1070. [CrossRef] [PubMed]

24. Beydoun, M.A.; Beydoun, H.A.; Wang, Y. Obesity and central obesity as risk factors for incident dementia and its subtypes: A systematic review and meta-analysis. Obesity Rev. 2008, 9, 204-218. [CrossRef] [PubMed]

25. Arrieta-Cruz, I.; Gutierrez-Juarez, R. The role of insulin resistance and glucose metabolism dysregulation in the development of Alzheimer s disease. Rev. Investig. Clin. 2016, 68, 53-58. [PubMed]

26. Faghihi, M.A.; Modarresi, F.; Khalil, A.M.; Wood, D.E.; Sahagan, B.G.; Morgan, T.E.; Finch, C.E.; St Laurent, G., 3rd; Kenny, P.J.; Wahlestedt, C. Expression of a noncoding RNA is elevated in Alzheimer's disease and drives rapid feed-forward regulation of beta-secretase. Nat. Med. 2008, 14, 723-730. [CrossRef] [PubMed] 
27. Julien, C.; Tremblay, C.; Phivilay, A.; Berthiaume, L.; Emond, V.; Julien, P.; Calon, F. High-fat diet aggravates amyloid-beta and tau pathologies in the 3xTg-AD mouse model. Neurobiol. Aging 2010, 31, 1516-1531. [CrossRef] [PubMed]

28. Bruehl, H.; Wolf, O.T.; Sweat, V.; Tirsi, A.; Richardson, S.; Convit, A. Modifiers of cognitive function and brain structure in middle-aged and elderly individuals with type 2 diabetes mellitus. Brain Res. 2009, 1280, 186-194. [CrossRef] [PubMed]

29. Steen, E.; Terry, B.M.; Rivera, E.J.; Cannon, J.L.; Neely, T.R.; Tavares, R.; Xu, X.J.; Wands, J.R.; de la Monte, S.M. Impaired insulin and insulin-like growth factor expression and signaling mechanisms in Alzheimer's disease-is this type 3 diabetes? J. Alzheimer's Dis. 2005, 7, 63-80. [CrossRef]

30. Rivera, E.J.; Goldin, A.; Fulmer, N.; Tavares, R.; Wands, J.R.; de la Monte, S.M. Insulin and insulin-like growth factor expression and function deteriorate with progression of Alzheimer's disease: Link to brain reductions in acetylcholine. J. Alzheimer's Dis. 2005, 8, 247-268. [CrossRef]

31. Hoyer, S. Causes and consequences of disturbances of cerebral glucose metabolism in sporadic Alzheimer disease: Therapeutic implications. Adv. Exp. Med. Biol. 2004, 541, 135-152. [PubMed]

32. Craft, S.; Asthana, S.; Cook, D.G.; Baker, L.D.; Cherrier, M.; Purganan, K.; Wait, C.; Petrova, A.; Latendresse, S.; Watson, G.S.; et al. Insulin dose-response effects on memory and plasma amyloid precursor protein in Alzheimer's disease: Interactions with apolipoprotein E. genotype. Psychoneuroendocrinology 2003, 28, 809-822. [CrossRef]

33. Hoyer, S. Glucose metabolism and insulin receptor signal transduction in Alzheimer disease. Eur. J. Pharmacol. 2004, 490, 115-125. [CrossRef] [PubMed]

34. Lester-Coll, N.; Rivera, E.J.; Soscia, S.J.; Doiron, K.; Wands, J.R.; de la Monte, S.M. Intracerebral streptozotocin model of type 3 diabetes: Relevance to sporadic Alzheimer's disease. J. Alzheimer's Dis. 2006, 9, 13-33. [CrossRef]

35. De la Monte, S.M.; Wands, J.R. Chronic gestational exposure to ethanol impairs insulin-stimulated survival and mitochondrial function in cerebellar neurons. Cell. Mol. Life Sci. 2002, 59, 882-893. [CrossRef] [PubMed]

36. Schubert, M.; Brazil, D.P.; Burks, D.J.; Kushner, J.A.; Ye, J.; Flint, C.L.; Farhang-Fallah, J.; Dikkes, P.; Warot, X.M.; Rio, C.; et al. Insulin receptor substrate-2 deficiency impairs brain growth and promotes tau phosphorylation. J. Neurosci. 2003, 23, 7084-7092. [CrossRef] [PubMed]

37. Sun, M.; Kraus, W.L. From discovery to function: The expanding roles of long noncoding RNAs in physiology and disease. Endocr. Rev. 2015, 36, 25-64. [CrossRef] [PubMed]

38. Wilusz, J.E.; Sunwoo, H.; Spector, D.L. Long noncoding RNAs: Functional surprises from the RNA world. Genes Dev. 2009, 23, 1494-1504. [CrossRef] [PubMed]

39. Kapranov, P.; Cheng, J.; Dike, S.; Nix, D.A.; Duttagupta, R.; Willingham, A.T.; Stadler, P.F.; Hertel, J.; Hackermuller, J.; Hofacker, I.L.; et al. RNA maps reveal new RNA classes and a possible function for pervasive transcription. Science 2007, 316, 1484-1488. [CrossRef] [PubMed]

40. Zhou, X.; Xu, J. Identification of Alzheimer's disease-associated long noncoding RNAs. Neurobiol. Aging 2015, 36, 2925-2931. [CrossRef] [PubMed]

41. Guttman, M.; Amit, I.; Garber, M.; French, C.; Lin, M.F.; Feldser, D.; Huarte, M.; Zuk, O.; Carey, B.W.; Cassady, J.P.; et al. Chromatin signature reveals over a thousand highly conserved large non-coding RNAs in mammals. Nature 2009, 458, 223-227. [CrossRef] [PubMed]

42. Cabili, M.N.; Trapnell, C.; Goff, L.; Koziol, M.; Tazon-Vega, B.; Regev, A.; Rinn, J.L. Integrative annotation of human large intergenic noncoding RNAs reveals global properties and specific subclasses. Genes Dev. 2011, 25, 1915-1927. [CrossRef] [PubMed]

43. Derrien, T.; Johnson, R.; Bussotti, G.; Tanzer, A.; Djebali, S.; Tilgner, H.; Guernec, G.; Martin, D.; Merkel, A.; Knowles, D.G.; et al. The GENCODE v7 catalog of human long noncoding RNAs: Analysis of their gene structure, evolution, and expression. Genome Res. 2012, 22, 1775-1789. [CrossRef] [PubMed]

44. Gong, Z.; Zhang, S.; Zhang, W.; Huang, H.; Li, Q.; Deng, H.; Ma, J.; Zhou, M.; Xiang, J.; Wu, M.; et al. Long non-coding RNAs in cancer. Sci. China Life Sci. 2012, 55, 1120-1124. [CrossRef] [PubMed]

45. Peng, L.; Yuan, X.; Jiang, B.; Tang, Z.; Li, G.C. LncRNAs: Key players and novel insights into cervical cancer. Tumour Biol. 2016, 37, 2779-2788. [CrossRef] [PubMed]

46. Rinn, J.L.; Chang, H.Y. Genome regulation by long noncoding RNAs. Annu. Rev. Biochem. 2012, 81, $145-166$. [CrossRef] [PubMed] 
47. Zhang, K.; Shi, Z.M.; Chang, Y.N.; Hu, Z.M.; Qi, H.X.; Hong, W. The ways of action of long non-coding RNAs in cytoplasm and nucleus. Gene 2014, 547, 1-9. [CrossRef] [PubMed]

48. Rinn, J.L.; Kertesz, M.; Wang, J.K.; Squazzo, S.L.; Xu, X.; Brugmann, S.A.; Goodnough, L.H.; Helms, J.A.; Farnham, P.J.; Segal, E.; et al. Functional demarcation of active and silent chromatin domains in human HOX loci by noncoding RNAs. Cell 2007, 129, 1311-1323. [CrossRef] [PubMed]

49. Wang, X.; Arai, S.; Song, X.; Reichart, D.; Du, K.; Pascual, G.; Tempst, P.; Rosenfeld, M.G.; Glass, C.K.; Kurokawa, R. Induced ncRNAs allosterically modify RNA-binding proteins in cis to inhibit transcription. Nature 2008, 454, 126-130. [CrossRef] [PubMed]

50. Zhao, X.Y.; Li, S.; Wang, G.X.; Yu, Q.; Lin, J.D. A long noncoding RNA transcriptional regulatory circuit drives thermogenic adipocyte differentiation. Mol. Cell 2014, 55, 372-382. [CrossRef] [PubMed]

51. Khanduja, J.S.; Calvo, I.A.; Joh, R.I.; Hill, I.T.; Motamedi, M. Nuclear Noncoding RNAs and Genome Stability. Mol. Cell 2016, 63, 7-20. [CrossRef] [PubMed]

52. Munschauer, M.; Nguyen, C.T.; Sirokman, K.; Hartigan, C.R.; Hogstrom, L.; Engreitz, J.M.; Ulirsch, J.C.; Fulco, C.P.; Subramanian, V.; Chen, J.; et al. The NORAD lncRNA assembles a topoisomerase complex critical for genome stability. Nature 2018, 561, 132-136. [CrossRef] [PubMed]

53. Yang, C.; Li, X.; Wang, Y.; Zhao, L.; Chen, W. Long non-coding RNA UCA1 regulated cell cycle distribution via CREB through PI3-K dependent pathway in bladder carcinoma cells. Gene 2012, 496, 8-16. [CrossRef] [PubMed]

54. Magistri, M.; Faghihi, M.A.; St Laurent, G., 3rd; Wahlestedt, C. Regulation of chromatin structure by long noncoding RNAs: Focus on natural antisense transcripts. Trends Genet. 2012, 28, 389-396. [CrossRef] [PubMed]

55. Faghihi, M.A.; Zhang, M.; Huang, J.; Modarresi, F.; Van der Brug, M.P.; Nalls, M.A.; Cookson, M.R.; St-Laurent, G., 3rd; Wahlestedt, C. Evidence for natural antisense transcript-mediated inhibition of microRNA function. Genome Biol. 2010, 11, R56. [CrossRef] [PubMed]

56. Yang, G.; Lu, X.; Yuan, L. LncRNA: A link between RNA and cancer. Biochim. Biophys. Acta 2014, 1839, 1097-1109. [CrossRef] [PubMed]

57. Bhan, A.; Soleimani, M.; Mandal, S.S. Long Noncoding RNA and Cancer: A. New Paradigm. Cancer Res. 2017, 77, 3965-3981. [CrossRef] [PubMed]

58. Shen, S.; Jiang, H.; Bei, Y.; Xiao, J.; Li, X. Long Non-Coding RNAs in Cardiac Remodeling. Cell. Physiol. Biochem. 2017, 41, 1830-1837. [CrossRef] [PubMed]

59. Dechamethakun, S.; Muramatsu, M. Long noncoding RNA variations in cardiometabolic diseases. J. Hum. Genet. 2017, 62, 97-104. [CrossRef] [PubMed]

60. Aprea, J.; Prenninger, S.; Dori, M.; Ghosh, T.; Monasor, L.S.; Wessendorf, E.; Zocher, S.; Massalini, S.; Alexopoulou, D.; Lesche, M.; et al. Transcriptome sequencing during mouse brain development identifies long non-coding RNAs functionally involved in neurogenic commitment. EMBO J. 2013, 32, 3145-3160. [CrossRef] [PubMed]

61. Sunwoo, J.S.; Lee, S.T.; Im, W.; Lee, M.; Byun, J.I.; Jung, K.H.; Park, K.I.; Jung, K.Y.; Lee, S.K.; Chu, K.; et al. Altered Expression of the Long Noncoding RNA NEAT1 in Huntington's Disease. Mol. Neurobiol. 2017, 54, 1577-1586. [CrossRef] [PubMed]

62. Liu, E.Y.; Cali, C.P.; Lee, E.B. RNA metabolism in neurodegenerative disease. Dis. Models Mech. 2017, 10, 509-518. [CrossRef] [PubMed]

63. Wei, S.; Du, M.; Jiang, Z.; Hausman, G.J.; Zhang, L.; Dodson, M.V. Long noncoding RNAs in regulating adipogenesis: New RNAs shed lights on obesity. Cell. Mol. Life Sci. 2016, 73, 2079-2087. [CrossRef] [PubMed]

64. Bussiere, T.; Gold, G.; Kovari, E.; Giannakopoulos, P.; Bouras, C.; Perl, D.P.; Morrison, J.H.; Hof, P.R. Stereologic analysis of neurofibrillary tangle formation in prefrontal cortex area 9 in aging and Alzheimer's disease. Neuroscience 2003, 117, 577-592. [CrossRef]

65. Mus, E.; Hof, P.R.; Tiedge, H. Dendritic BC200 RNA in aging and in Alzheimer's disease. Proc. Natl. Acad. Sci. USA 2007, 104, 10679-10684. [CrossRef] [PubMed]

66. Bernard, D.; Prasanth, K.V.; Tripathi, V.; Colasse, S.; Nakamura, T.; Xuan, Z.; Zhang, M.Q.; Sedel, F.; Jourdren, L.; Coulpier, F.; et al. A long nuclear-retained non-coding RNA regulates synaptogenesis by modulating gene expression. EMBO J. 2010, 29, 3082-3093. [CrossRef] [PubMed]

67. Yan, C.; Chen, J.; Chen, N. Long noncoding RNA MALAT1 promotes hepatic steatosis and insulin resistance by increasing nuclear SREBP-1c protein stability. Sci. Rep. 2016, 6, 22640. [CrossRef] [PubMed] 
68. Wang, J.; Zhao, H.; Fan, Z.; Li, G.; Ma, Q.; Tao, Z.; Wang, R.; Feng, J.; Luo, Y. Long Noncoding RNA H19 Promotes Neuroinflammation in Ischemic Stroke by Driving Histone Deacetylase 1-Dependent M1 Microglial Polarization. Stroke 2017, 48, 2211-2221. [CrossRef] [PubMed]

69. Gao, Y.; Wu, F.; Zhou, J.; Yan, L.; Jurczak, M.J.; Lee, H.Y.; Yang, L.; Mueller, M.; Zhou, X.B.; Dandolo, L.; et al. The H19/let-7 double-negative feedback loop contributes to glucose metabolism in muscle cells. Nucleic Acids Res. 2014, 42, 13799-13811. [CrossRef] [PubMed]

70. Gui, Y.; Liu, H.; Zhang, L.; Lv, W.; Hu, X. Altered microRNA profiles in cerebrospinal fluid exosome in Parkinson disease and Alzheimer disease. Oncotarget 2015, 6, 37043-37053. [CrossRef] [PubMed]

71. Carrieri, C.; Cimatti, L.; Biagioli, M.; Beugnet, A.; Zucchelli, S.; Fedele, S.; Pesce, E.; Ferrer, I.; Collavin, L.; Santoro, C.; et al. Long non-coding antisense RNA controls Uchl1 translation through an embedded SINEB2 repeat. Nature 2012, 491, 454-457. [CrossRef] [PubMed]

72. Choi, S.H.; Bylykbashi, E.; Chatila, Z.K.; Lee, S.W.; Pulli, B.; Clemenson, G.D.; Kim, E.; Rompala, A.; Oram, M.K.; Asselin, C.; et al. Combined adult neurogenesis and BDNF mimic exercise effects on cognition in an Alzheimer's mouse model. Science 2018, 361. [CrossRef] [PubMed]

73. Hollands, C.; Bartolotti, N.; Lazarov, O. Alzheimer's Disease and Hippocampal Adult Neurogenesis; Exploring Shared Mechanisms. Front. Neurosci. 2016, 10, 178. [CrossRef] [PubMed]

74. Abrous, D.N.; Koehl, M.; Le Moal, M. Adult neurogenesis: From precursors to network and physiology. Physiol. Rev. 2005, 85, 523-569. [CrossRef] [PubMed]

75. Seaberg, R.M.; van der Kooy, D. Adult rodent neurogenic regions: The ventricular subependyma contains neural stem cells, but the dentate gyrus contains restricted progenitors. J. Neurosci. 2002, 22, 1784-1793. [CrossRef] [PubMed]

76. Colucci-D'Amato, L.; Bonavita, V.; di Porzio, U. The end of the central dogma of neurobiology: Stem cells and neurogenesis in adult CNS. Neurol. Sci. 2006, 27, 266-270. [CrossRef] [PubMed]

77. Jin, K.; Zhu, Y.; Sun, Y.; Mao, X.O.; Xie, L.; Greenberg, D.A. Vascular endothelial growth factor (VEGF) stimulates neurogenesis in vitro and in vivo. Proc. Natl. Acad. Sci. USA 2002, 99, 11946-11950. [CrossRef] [PubMed]

78. Ramos, A.D.; Diaz, A.; Nellore, A.; Delgado, R.N.; Park, K.Y.; Gonzales-Roybal, G.; Oldham, M.C.; Song, J.S.; Lim, D.A. Integration of genome-wide approaches identifies lncRNAs of adult neural stem cells and their progeny in vivo. Cell Stem Cell 2013, 12, 616-628. [CrossRef] [PubMed]

79. Wang, J.; Lucas, B.A.; Maquat, L.E. New gene expression pipelines gush lncRNAs. Genome Biol. 2013, 14, 117. [CrossRef] [PubMed]

80. Mercer, T.R.; Qureshi, I.A.; Gokhan, S.; Dinger, M.E.; Li, G.; Mattick, J.S.; Mehler, M.F. Long noncoding RNAs in neuronal-glial fate specification and oligodendrocyte lineage maturation. BMC Neurosci. 2010, 11, 14. [CrossRef] [PubMed]

81. Qureshi, I.A.; Mehler, M.F. Emerging roles of non-coding RNAs in brain evolution, development, plasticity and disease. Nat. Rev. Neurosci. 2012, 13, 528-541. [CrossRef] [PubMed]

82. Ng, S.Y.; Lin, L.; Soh, B.S.; Stanton, L.W. Long noncoding RNAs in development and disease of the central nervous system. Trends Genet. 2013, 29, 461-468. [CrossRef] [PubMed]

83. Chen, L.; Feng, P.; Zhu, X.; He, S.; Duan, J.; Zhou, D. Long non-coding RNA Malat1 promotes neurite outgrowth through activation of ERK/MAPK signalling pathway in N2a cells. J. Cell. Mol. Med. 2016, 20, 2102-2110. [CrossRef] [PubMed]

84. Govek, E.E.; Newey, S.E.; Van Aelst, L. The role of the Rho GTPases in neuronal development. Genes Dev. 2005, 19, 1-49. [CrossRef] [PubMed]

85. Ng, S.Y.; Bogu, G.K.; Soh, B.S.; Stanton, L.W. The long noncoding RNA RMST interacts with SOX2 to regulate neurogenesis. Mol. Cell 2013, 51, 349-359. [CrossRef] [PubMed]

86. Noor, A.; Zahid, S. Alterations in adult hippocampal neurogenesis, aberrant protein s-nitrosylation, and associated spatial memory loss in streptozotocin-induced diabetes mellitus type 2 mice. Iran. J. Basic Med. Sci. 2017, 20, 1159-1165. [CrossRef] [PubMed]

87. Walsh, D.M.; Selkoe, D.J. Deciphering the molecular basis of memory failure in Alzheimer's disease. Neuron 2004, 44, 181-193. [CrossRef] [PubMed]

88. Musardo, S.; Marcello, E. Synaptic dysfunction in Alzheimer's disease: From the role of amyloid beta-peptide to the alpha-secretase ADAM10. Eur. J. Pharmacol. 2017, 817, 30-37. [CrossRef] [PubMed] 
89. Kordower, J.H.; Chu, Y.; Stebbins, G.T.; DeKosky, S.T.; Cochran, E.J.; Bennett, D.; Mufson, E.J. Loss and atrophy of layer II entorhinal cortex neurons in elderly people with mild cognitive impairment. Ann. Neurol. 2001, 49, 202-213. [CrossRef]

90. Sheng, M.; Sabatini, B.L.; Sudhof, T.C. Synapses and Alzheimer's disease. Cold Spring Harb. Perspect. Biol. 2012, 4. [CrossRef] [PubMed]

91. Nistico, R.; Pignatelli, M.; Piccinin, S.; Mercuri, N.B.; Collingridge, G. Targeting synaptic dysfunction in Alzheimer's disease therapy. Mol. Neurobiol. 2012, 46, 572-587. [CrossRef] [PubMed]

92. Lin, D.; Pestova, T.V.; Hellen, C.U.; Tiedge, H. Translational control by a small RNA: Dendritic BC1 RNA targets the eukaryotic initiation factor 4A helicase mechanism. Mol. Cell. Biol. 2008, 28, 3008-3019. [CrossRef] [PubMed]

93. Wang, H.; Iacoangeli, A.; Popp, S.; Muslimov, I.A.; Imataka, H.; Sonenberg, N.; Lomakin, I.B.; Tiedge, H. Dendritic BC1 RNA: Functional role in regulation of translation initiation. J. Neurosci. 2002, 22, 10232-10241. [CrossRef] [PubMed]

94. Zhong, J.; Chuang, S.C.; Bianchi, R.; Zhao, W.; Lee, H.; Fenton, A.A.; Wong, R.K.; Tiedge, H. BC1 regulation of metabotropic glutamate receptor-mediated neuronal excitability. J. Neurosci. 2009, 29, 9977-9986. [CrossRef] [PubMed]

95. Centonze, D.; Rossi, S.; Napoli, I.; Mercaldo, V.; Lacoux, C.; Ferrari, F.; Ciotti, M.T.; De Chiara, V.; Prosperetti, C.; Maccarrone, M.; et al. The brain cytoplasmic RNA BC1 regulates dopamine D2 receptor-mediated transmission in the striatum. J. Neurosci. 2007, 27, 8885-8892. [CrossRef] [PubMed]

96. Mercer, T.R.; Dinger, M.E.; Sunkin, S.M.; Mehler, M.F.; Mattick, J.S. Specific expression of long noncoding RNAs in the mouse brain. Proc. Natl. Acad. Sci. USA 2008, 105, 716-721. [CrossRef] [PubMed]

97. Barry, G.; Briggs, J.A.; Vanichkina, D.P.; Poth, E.M.; Beveridge, N.J.; Ratnu, V.S.; Nayler, S.P.; Nones, K.; Hu, J.; Bredy, T.W.; et al. The long non-coding RNA Gomafu is acutely regulated in response to neuronal activation and involved in schizophrenia-associated alternative splicing. Mol. Psychiatry 2014, 19, 486-494. [CrossRef] [PubMed]

98. Haass, C.; Selkoe, D.J. Soluble protein oligomers in neurodegeneration: Lessons from the Alzheimer's amyloid beta-peptide. Nat. Rev. Mol. Cell Biol. 2007, 8, 101-112. [CrossRef] [PubMed]

99. Ma, Q.L.; Galasko, D.R.; Ringman, J.M.; Vinters, H.V.; Edland, S.D.; Pomakian, J.; Ubeda, O.J.; Rosario, E.R.; Teter, B.; Frautschy, S.A.; et al. Reduction of SorLA/LR11, a sorting protein limiting beta-amyloid production, in Alzheimer disease cerebrospinal fluid. Arch. Neurol. 2009, 66, 448-457. [CrossRef] [PubMed]

100. Ciarlo, E.; Massone, S.; Penna, I.; Nizzari, M.; Gigoni, A.; Dieci, G.; Russo, C.; Florio, T.; Cancedda, R.; Pagano, A. An intronic ncRNA-dependent regulation of SORL1 expression affecting Abeta formation is upregulated in post-mortem Alzheimer's disease brain samples. Dis. Models Mech. 2013, 6, 424-433. [CrossRef] [PubMed]

101. Lee, J.H.; Barral, S.; Reitz, C. The neuronal sortilin-related receptor gene SORL1 and late-onset Alzheimer's disease. Curr. Neurol. Neurosci. Rep. 2008, 8, 384-391. [CrossRef] [PubMed]

102. Boland, B.; Kumar, A.; Lee, S.; Platt, F.M.; Wegiel, J.; Yu, W.H.; Nixon, R.A. Autophagy induction and autophagosome clearance in neurons: Relationship to autophagic pathology in Alzheimer's disease. J. Neurosci. 2008, 28, 6926-6937. [CrossRef] [PubMed]

103. Ma, H.; Lesne, S.; Kotilinek, L.; Steidl-Nichols, J.V.; Sherman, M.; Younkin, L.; Younkin, S.; Forster, C.; Sergeant, N.; Delacourte, A.; et al. Involvement of beta-site APP cleaving enzyme 1 (BACE1) in amyloid precursor protein-mediated enhancement of memory and activity-dependent synaptic plasticity. Proc. Natl. Acad. Sci. USA 2007, 104, 8167-8172. [CrossRef] [PubMed]

104. Laird, F.M.; Cai, H.; Savonenko, A.V.; Farah, M.H.; He, K.; Melnikova, T.; Wen, H.; Chiang, H.C.; Xu, G.; Koliatsos, V.E.; et al. BACE1, a major determinant of selective vulnerability of the brain to amyloid-beta amyloidogenesis, is essential for cognitive, emotional, and synaptic functions. J. Neurosci. 2005, 25, 11693-11709. [CrossRef] [PubMed]

105. Dislich, B.; Lichtenthaler, S.F. The Membrane-Bound Aspartyl Protease BACE1: Molecular and Functional Properties in Alzheimer's Disease and Beyond. Front. Physiol. 2012, 3, 8. [CrossRef] [PubMed]

106. Kang, M.J.; Abdelmohsen, K.; Hutchison, E.R.; Mitchell, S.J.; Grammatikakis, I.; Guo, R.; Noh, J.H.; Martindale, J.L.; Yang, X.; Lee, E.K.; et al. HuD regulates coding and noncoding RNA to induce APP $\rightarrow$ Abeta processing. Cell Rep. 2014, 7, 1401-1409. [CrossRef] [PubMed] 
107. Massone, S.; Ciarlo, E.; Vella, S.; Nizzari, M.; Florio, T.; Russo, C.; Cancedda, R.; Pagano, A. NDM29, a RNA polymerase III-dependent non coding RNA, promotes amyloidogenic processing of APP and amyloid beta secretion. Biochim. Biophys. Acta 2012, 1823, 1170-1177. [CrossRef] [PubMed]

108. Massone, S.; Vassallo, I.; Fiorino, G.; Castelnuovo, M.; Barbieri, F.; Borghi, R.; Tabaton, M.; Robello, M.; Gatta, E.; Russo, C.; et al. 17A, a novel non-coding RNA, regulates GABA B alternative splicing and signaling in response to inflammatory stimuli and in Alzheimer disease. Neurobiol. Dis. 2011, 41, 308-317. [CrossRef] [PubMed]

109. Strobel, S.; Grunblatt, E.; Riederer, P.; Heinsen, H.; Arzberger, T.; Al-Sarraj, S.; Troakes, C.; Ferrer, I.; Monoranu, C.M. Changes in the expression of genes related to neuroinflammation over the course of sporadic Alzheimer's disease progression: CX3CL1, TREM2, and PPARgamma. J. Neural Transm. 2015, 122, 1069-1076. [CrossRef] [PubMed]

110. Amid, C.; Bahr, A.; Mujica, A.; Sampson, N.; Bikar, S.E.; Winterpacht, A.; Zabel, B.; Hankeln, T.; Schmidt, E.R. Comparative genomic sequencing reveals a strikingly similar architecture of a conserved syntenic region on human chromosome 11p15.3 (including gene ST5) and mouse chromosome 7. Cytogenet. Cell Genet. 2001, 93, 284-290. [CrossRef] [PubMed]

111. De Preter, K.; Vandesompele, J.; Menten, B.; Carr, P.; Fiegler, H.; Edsjo, A.; Carter, N.P.; Yigit, N.; Waelput, W.; Van Roy, N.; et al. Positional and functional mapping of a neuroblastoma differentiation gene on chromosome 11. BMC Genom. 2005, 6, 97. [CrossRef] [PubMed]

112. Gavazzo, P.; Vassalli, M.; Costa, D.; Pagano, A. Novel ncRNAs transcribed by Pol III and elucidation of their functional relevance by biophysical approaches. Front. Cell. Neurosci. 2013, 7, 203. [CrossRef] [PubMed]

113. Vella, S.; Penna, I.; Longo, L.; Pioggia, G.; Garbati, P.; Florio, T.; Rossi, F.; Pagano, A. Perhexiline maleate enhances antitumor efficacy of cisplatin in neuroblastoma by inducing over-expression of NDM29 ncRNA. Sci. Rep. 2015, 5, 18144. [CrossRef] [PubMed]

114. Heneka, M.T.; Kummer, M.P.; Latz, E. Innate immune activation in neurodegenerative disease. Nat. Rev. Immunol. 2014, 14, 463-477. [CrossRef] [PubMed]

115. Heneka, M.T.; Carson, M.J.; El Khoury, J.; Landreth, G.E.; Brosseron, F.; Feinstein, D.L.; Jacobs, A.H.; Wyss-Coray, T.; Vitorica, J.; Ransohoff, R.M.; et al. Neuroinflammation in Alzheimer's disease. Lancet Neurol. 2015, 14, 388-405. [CrossRef]

116. Heward, J.A.; Lindsay, M.A. Long non-coding RNAs in the regulation of the immune response. Trends Immunol. 2014, 35, 408-419. [CrossRef] [PubMed]

117. Chen, R.; Liu, L.; Xiao, M.; Wang, F.; Lin, X. Microarray expression profile analysis of long noncoding RNAs in premature brain injury: A novel point of view. Neuroscience 2016, 319, 123-133. [CrossRef] [PubMed]

118. Ilott, N.E.; Heward, J.A.; Roux, B.; Tsitsiou, E.; Fenwick, P.S.; Lenzi, L.; Goodhead, I.; Hertz-Fowler, C.; Heger, A.; Hall, N.; et al. Long non-coding RNAs and enhancer RNAs regulate the lipopolysaccharide-induced inflammatory response in human monocytes. Nat. Commun. 2014, 5, 3979. [CrossRef]

119. Hu, G.; Tang, Q.; Sharma, S.; Yu, F.; Escobar, T.M.; Muljo, S.A.; Zhu, J.; Zhao, K. Expression and regulation of intergenic long noncoding RNAs during T cell development and differentiation. Nat. Immunol. 2013, 14, 1190-1198. [CrossRef] [PubMed]

120. Cui, H.; Xie, N.; Tan, Z.; Banerjee, S.; Thannickal, V.J.; Abraham, E.; Liu, G. The human long noncoding RNA lnc-IL7R regulates the inflammatory response. Eur. J. Immunol. 2014, 44, 2085-2095. [CrossRef] [PubMed]

121. Carpenter, S.; Aiello, D.; Atianand, M.K.; Ricci, E.P.; Gandhi, P.; Hall, L.L.; Byron, M.; Monks, B.; Henry-Bezy, M.; Lawrence, J.B.; et al. A long noncoding RNA mediates both activation and repression of immune response genes. Science 2013, 341, 789-792. [CrossRef] [PubMed]

122. Rapicavoli, N.A.; Qu, K.; Zhang, J.; Mikhail, M.; Laberge, R.M.; Chang, H.Y. A mammalian pseudogene lncRNA at the interface of inflammation and anti-inflammatory therapeutics. eLife 2013, 2, e00762. [CrossRef] [PubMed]

123. Clemson, C.M.; Hutchinson, J.N.; Sara, S.A.; Ensminger, A.W.; Fox, A.H.; Chess, A.; Lawrence, J.B. An architectural role for a nuclear noncoding RNA: NEAT1 RNA is essential for the structure of paraspeckles. Mol. Cell 2009, 33, 717-726. [CrossRef] [PubMed] 
124. Imamura, K.; Imamachi, N.; Akizuki, G.; Kumakura, M.; Kawaguchi, A.; Nagata, K.; Kato, A.; Kawaguchi, Y.; Sato, H.; Yoneda, M.; et al. Long noncoding RNA NEAT1-dependent SFPQ relocation from promoter region to paraspeckle mediates IL8 expression upon immune stimuli. Mol. Cell 2014, 53, 393-406. [CrossRef] [PubMed]

125. Baune, B.T.; Ponath, G.; Golledge, J.; Varga, G.; Arolt, V.; Rothermundt, M.; Berger, K. Association between IL-8 cytokine and cognitive performance in an elderly general population-the MEMO-Study. Neurobiol. Aging 2008, 29, 937-944. [CrossRef] [PubMed]

126. Bao, M.H.; Szeto, V.; Yang, B.B.; Zhu, S.Z.; Sun, H.S.; Feng, Z.P. Long non-coding RNAs in ischemic stroke. Cell Death Dis. 2018, 9, 281. [CrossRef] [PubMed]

127. Kumar, A.; Loane, D.J. Neuroinflammation after traumatic brain injury: Opportunities for therapeutic intervention. Brain Behav. Immun. 2012, 26, 1191-1201. [CrossRef] [PubMed]

128. Yin, X.J.; Chen, Z.Y.; Zhu, X.N.; Hu, J.J. Loss of PAFR prevents neuroinflammation and brain dysfunction after traumatic brain injury. Sci. Rep. 2017, 7, 40614. [CrossRef] [PubMed]

129. Feng, J.; Xing, W.; Xie, L. Regulatory Roles of MicroRNAs in Diabetes. Int. J. Mol. Sci. 2016, 17, 1729. [CrossRef] [PubMed]

130. De Felice, F.G.; Lourenco, M.V.; Ferreira, S.T. How does brain insulin resistance develop in Alzheimer's disease? Alzheimer's Dement. 2014, 10, S26-S32. [CrossRef] [PubMed]

131. Talbot, K. Brain insulin resistance in Alzheimer's disease and its potential treatment with GLP-1 analogs. Neurodegener. Dis. Manag. 2014, 4, 31-40. [CrossRef] [PubMed]

132. An, Y.; Varma, V.R.; Varma, S.; Casanova, R.; Dammer, E.; Pletnikova, O.; Chia, C.W.; Egan, J.M.; Ferrucci, L.; Troncoso, J.; et al. Evidence for brain glucose dysregulation in Alzheimer's disease. Alzheimer's Dement. 2017. [CrossRef]

133. Millis, M.P.; Bowen, D.; Kingsley, C.; Watanabe, R.M.; Wolford, J.K. Variants in the plasmacytoma variant translocation gene (PVT1) are associated with end-stage renal disease attributed to type 1 diabetes. Diabetes 2007, 56, 3027-3032. [CrossRef] [PubMed]

134. Bomfim, T.R.; Forny-Germano, L.; Sathler, L.B.; Brito-Moreira, J.; Houzel, J.C.; Decker, H.; Silverman, M.A.; Kazi, H.; Melo, H.M.; McClean, P.L.; et al. An anti-diabetes agent protects the mouse brain from defective insulin signaling caused by Alzheimer's disease-associated Abeta oligomers. J. Clin. Investig. 2012, 122, 1339-1353. [CrossRef] [PubMed]

135. Li, Z.; Li, J.; Tang, N. Long noncoding RNA Malat1 is a potent autophagy inducer protecting brain microvascular endothelial cells against oxygen-glucose deprivation/reoxygenation-induced injury by sponging miR-26b and upregulating ULK2 expression. Neuroscience 2017, 354, 1-10. [CrossRef] [PubMed]

136. Liu, C.; Li, C.P.; Wang, J.J.; Shan, K.; Liu, X.; Yan, B. RNCR3 knockdown inhibits diabetes mellitus-induced retinal reactive gliosis. Biochem. Bioph. Res. 2016, 479, 198-203. [CrossRef] [PubMed]

137. Jang, W.I.; Kim, M.S.; Kang, S.H.; Jo, A.J.; Kim, Y.J.; Tchoe, H.J.; Park, C.M.; Kim, H.J.; Choi, J.A.; Choi, H.J.; et al. Association between metformin use and mortality in patients with type 2 diabetes mellitus and localized resectable pancreatic cancer: A nationwide population-based study in Korea. Oncotarget 2017, 8, 9587-9596. [CrossRef] [PubMed]

138. Zhu, X.; Wu, Y.B.; Zhou, J.; Kang, D.M. Upregulation of lncRNA MEG3 promotes hepatic insulin resistance via increasing FoxO1 expression. Biochem. Bioph. Res. 2016, 469, 319-325. [CrossRef] [PubMed]

139. You, L.; Wang, N.; Yin, D.; Wang, L.; Jin, F.; Zhu, Y.; Yuan, Q.; De, W. Downregulation of Long Noncoding RNA Meg3 Affects Insulin Synthesis and Secretion in Mouse Pancreatic Beta Cells. J. Cell. Physiol. 2016, 231, 852-862. [CrossRef] [PubMed]

140. Wallace, C.; Smyth, D.J.; Maisuria-Armer, M.; Walker, N.M.; Todd, J.A.; Clayton, D.G. The imprinted DLK1-MEG3 gene region on chromosome 14q32.2 alters susceptibility to type 1 diabetes. Nat. Genet. 2010, 42, 68-71. [CrossRef] [PubMed]

141. Hung, C.L.; Wang, L.Y.; Yu, Y.L.; Chen, H.W.; Srivastava, S.; Petrovics, G.; Kung, H.J. A long noncoding RNA connects c-Myc to tumor metabolism. Proc. Natl. Acad. Sci. USA 2014, 111, 18697-18702. [CrossRef] [PubMed]

142. Magistri, M.; Velmeshev, D.; Makhmutova, M.; Faghihi, M.A. Transcriptomics Profiling of Alzheimer's Disease Reveal Neurovascular Defects, Altered Amyloid-beta Homeostasis, and Deregulated Expression of Long Noncoding RNAs. J. Alzheimer's Dis. 2015, 48, 647-665. [CrossRef] [PubMed] 
143. Lanz, R.B.; Razani, B.; Goldberg, A.D.; O'Malley, B.W. Distinct RNA motifs are important for coactivation of steroid hormone receptors by steroid receptor RNA activator (SRA). Proc. Natl. Acad. Sci. USA 2002, 99, 16081-16086. [CrossRef] [PubMed]

144. Awata, T.; Yamashita, H.; Kurihara, S.; Morita-Ohkubo, T.; Miyashita, Y.; Katayama, S.; Mori, K.; Yoneya, S.; Kohda, M.; Okazaki, Y.; et al. A genome-wide association study for diabetic retinopathy in a Japanese population: Potential association with a long intergenic non-coding RNA. PLoS ONE 2014, 9, e111715. [CrossRef] [PubMed]

145. Liu, J.Y.; Yao, J.; Li, X.M.; Song, Y.C.; Wang, X.Q.; Li, Y.J.; Yan, B.; Jiang, Q. Pathogenic role of lncRNA-MALAT1 in endothelial cell dysfunction in diabetes mellitus. Cell Death Dis. 2014, 5, e1506. [CrossRef] [PubMed]

146. Puthanveetil, P.; Chen, S.; Feng, B.; Gautam, A.; Chakrabarti, S. Long non-coding RNA MALAT1 regulates hyperglycaemia induced inflammatory process in the endothelial cells. J. Cell. Mol. Med. 2015, 19, 1418-1425. [CrossRef] [PubMed]

147. Gejl, M.; Brock, B.; Egefjord, L.; Vang, K.; Rungby, J.; Gjedde, A. Blood-Brain Glucose Transfer in Alzheimer's disease: Effect of GLP-1 Analog Treatment. Sci. Rep. 2017, 7, 17490. [CrossRef] [PubMed]

148. Chalei, V.; Sansom, S.N.; Kong, L.; Lee, S.; Montiel, J.F.; Vance, K.W.; Ponting, C.P. The long non-coding RNA Dali is an epigenetic regulator of neural differentiation. eLife 2014, 3, e04530. [CrossRef] [PubMed]

149. Bond, A.M.; Vangompel, M.J.; Sametsky, E.A.; Clark, M.F.; Savage, J.C.; Disterhoft, J.F.; Kohtz, J.D. Balanced gene regulation by an embryonic brain ncRNA is critical for adult hippocampal GABA circuitry. Nat. Neurosci. 2009, 12, 1020-1027. [CrossRef] [PubMed]

150. Ramos, A.D.; Andersen, R.E.; Liu, S.J.; Nowakowski, T.J.; Hong, S.J.; Gertz, C.; Salinas, R.D.; Zarabi, H.; Kriegstein, A.R.; Lim, D.A. The long noncoding RNA Pnky regulates neuronal differentiation of embryonic and postnatal neural stem cells. Cell Stem Cell 2015, 16, 439-447. [CrossRef] [PubMed]

151. Li, Z.; Hao, S.; Yin, H.; Gao, J.; Yang, Z. Autophagy ameliorates cognitive impairment through activation of PVT1 and apoptosis in diabetes mice. Behav. Brain Res. 2016, 305, 265-277. [CrossRef] [PubMed]

152. Liu, T.; Huang, Y.; Chen, J.; Chi, H.; Yu, Z.; Wang, J.; Chen, C. Attenuated ability of BACE1 to cleave the amyloid precursor protein via silencing long noncoding RNA BACE1AS expression. Mol. Med. Rep. 2014, 10, 1275-1281. [CrossRef] [PubMed]

153. Zhang, T.; Pang, P.; Fang, Z.; Guo, Y.; Li, H.; Li, X.; Tian, T.; Yang, X.; Chen, W.; Shu, S.; et al. Expression of BC1 Impairs Spatial Learning and Memory in Alzheimer's Disease Via APP Translation. Mol. Neurobiol. 2018, 55, 6007-6020. [CrossRef] [PubMed]

154. Cui, X.; Tan, J.; Shi, Y.; Sun, C.; Li, Y.; Ji, C.; Wu, J.; Zhang, Z.; Chen, S.; Guo, X.; et al. The long non-coding RNA Gm10768 activates hepatic gluconeogenesis by sequestering microRNA-214 in mice. J. Biol. Chem. 2018, 293, 4097-4109. [CrossRef] [PubMed]

155. Goyal, N.; Sivadas, A.; Shamsudheen, K.V.; Jayarajan, R.; Verma, A.; Sivasubbu, S.; Scaria, V.; Datta, M. RNA sequencing of $\mathrm{db} / \mathrm{db}$ mice liver identifies lncRNA H19 as a key regulator of gluconeogenesis and hepatic glucose output. Sci. Rep. 2017, 7, 8312. [CrossRef] [PubMed]

156. Wang, Y.; Hu, Y.; Sun, C.; Zhuo, S.; He, Z.; Wang, H.; Yan, M.; Liu, J.; Luan, Y.; Dai, C.; et al. Down-regulation of Risa improves insulin sensitivity by enhancing autophagy. FASEB J. 2016, 30, 3133-3145. [CrossRef] [PubMed]

157. Arnes, L.; Akerman, I.; Balderes, D.A.; Ferrer, J.; Sussel, L. Betalinc1 encodes a long noncoding RNA that regulates islet beta-cell formation and function. Genes Dev. 2016, 30, 502-507. [CrossRef] [PubMed]

158. Haring, T.; Haase, B.; Zini, E.; Hartnack, S.; Uebelhart, D.; Gaudenz, D.; Wichert, B.A. Overweight and impaired insulin sensitivity present in growing cats. J. Anim. Physiol. Anim. Nutr. 2013, 97, 813-819. [CrossRef] [PubMed]

(C) 2018 by the authors. Licensee MDPI, Basel, Switzerland. This article is an open access article distributed under the terms and conditions of the Creative Commons Attribution (CC BY) license (http:/ / creativecommons.org/licenses/by/4.0/). 